\title{
Discursive Strategies and Politics of (Neo-)colonialism: A Textual Analysis of Saadat Hassan Manto's Letters to Uncle Sam
}

\author{
Inayat Ullah ${ }^{1} \&$ Iman Aib ${ }^{1}$ \\ ${ }^{1}$ Department of Humanities (English), Faculty of Social Sciences, Air University, Islamabad, Pakistan \\ Correspondence: Inayat Ullah, Department of Humanities (English), Faculty of Social Sciences, Air University, \\ Islamabad, Pakistan. E-mail: inayat_ktk@yahoo.com
}

Received: May 23, 2017 Accepted: June 18, 2017 Online Published: July 21, 2017

doi:10.5539/ijel.v7n5p8 URL: http://doi.org/10.5539/ijel.v7n5p8

\begin{abstract}
Colonialism has been such a multifaceted and complicated phenomenon that it often juxtaposed the culture of the colonized in simultaneous assimilation of, and resistance to, the culture of the colonizers. Embedded in the theory of Post colonialism, this research aims at carrying out a qualitative analysis of discursive strategies used in Saadat Hassan Manto's literary work Letters to Uncle Sam from a neo-colonial perspective. It seeks to highlight the issues of globalization and the effects that it engendered upon the then newly-established independent state of Pakistan. The research findings conclude that globalization has resulted in putting an end to the so-called purity of culture. Manto, therefore, explicitly satirizes the super power (read the United States of America) for its hidden agendas of manipulating and exploiting the economic system as well as the cultural beliefs of Pakistan under the mask of prospering nations by building a global market to create a new means of dominance that works through consent.
\end{abstract}

Keywords: discursive strategies, colonization, resistance, globalization

\section{Introduction}

Colonialism has been a multifaceted phenomenon that has taken many forms and thus engendered diverse effects on the colonized world. With the apparent aim of educating nations, as Macaulay said in Indian Education: Minute of the 2nd of February, 1835 that "We must at present do our best to form a class of interpreters between us and millions whom we govern; a class of persons, Indian in blood and color, but English in tastes, in opinions, in morals and intellect" (Quoted. in Patke, 2006, p. 57)," the ideology of converting the colonized people into mere physically living tools to carry out the everyday chores of the vulnerable British Raj was at play.

A hidden agenda behind colonialism was the occupation of the lands to transform them into a commercial venture for the Western colonizing nations. As Judd (1998) argues that the desire for the establishment of an imperial structure was the most and foremost part of a colonial policy to establish a commercial venture. Hence, the seizing of the colonized lands, the exploitation of natural resources, and the establishment of industries and economic progress were not meant to aid to the colonized lands to secure a prosperous life for the locals, but to extract as much wealth as possible, and therefore build a capitalist system that may operate under the western hegemonic power.

The establishment of a capitalist country was a hegemonic ideological imperial agenda that was carried out in order to uphold economic and military power of one nation by another. Thus, colonialism is one of the forms of imperial agendas which is concerned with the settlement of colonizers within a colonized space. Childs \& Williams (1997) define imperialism as an indirect control of nations "under the protection of political, legal, and military consoles" (Qtd. in Mcloed, 2000, p. 8). Therefore, it can be argued that although colonialism has vanished today, imperialism still continues to exist and is constantly exercised as an indirect control of the colonized nations through capitalist ideologies. According to Lorimer (2008), the term imperialism came into being in 1890 as an alternative approach to the term empire, therefore, expanding the space of the British Empire from "little Englanders" (Lenin, 2008, p. 7) to a central land that extends beyond time and space. The term was then rapidly spread across the globe to define the contest between rival European states, thus giving birth to the Age of Imperialism.

Wolfe (1997) defines imperialism from two standpoints: on the one hand, imperialism is taken as an interchangeable term with colonialism, in that both may be reduced to define an "empire". On the other hand, 
adding to this definition are certain elaborative terms such as hegemony, globalization and dependency which may be summed up to a consensual gestalt. As Ullah \& Arif (2013) highlight the importance and value of the dawn of a representative literature that marks the dusk of colonialism, the present study aims to critically analyze the discursive strategies used to resist such manifestations of globalization and neo-colonialism which stem from the root of imperialism in the postcolonial writings of Saadat Hassan Manto's Letters to Uncle Sam. The research aims to answer the following questions:

1) How has imperialism engendered new forms of colonization in the Indian sub-continent after the Second World War?

2) How does Saadat Hasan Manto, from a postcolonial perspective, satirically criticize globalization as a new form of imperialist agenda in his work Letters to Uncle Sam?

\section{Objectives of the Research}

The present study aims to identify the means through which imperialism still continues to exist as a process of colonialism. Moreover, this research project endeavors to critically analyze the discursive strategies which are used by Saadat Hassan Manto in a bid to show resistance to globalization through his Letters to Uncle Sam.

\section{Statement of the Problem}

The process of colonialism has always involved an effort aimed at cultural erasure by the colonizers. This is done in order to create a general feeling of hopeless rootlessness among the colonized masses. This, in turn, makes the colonized look up to the colonizers' culture as a superior one and thus the colonized people mentally internalize the ultimate supremacy of the colonizers. One of the very important ways of attaining this goal has been through establishing new means of imperialist agendas in the form of globalization. The paradoxical situation in which the colonized nation is lurks has become significantly important to define. Therefore, this research aims at exploring the discursive ways in which a colonized nation has been resisting the Western hegemonic power in the works of Manto.

\section{Significance of the Study}

Globalization has for long been a hot topic of discussion across the world and is continuously engendering an array of meanings and notions. While some theorists praise globalization as having positive features of development and recognition, many others especially postcolonial theorists have satirically criticized the hidden agendas of globalization as a new means of imperialism. Since Saadat Hassan Manto is regarded as a revolutionary postcolonial Urdu writer, this study attempts to critically analyze discursive strategies in his groundbreaking work Letters to Uncle Sam in the light of neo-colonialism theory.

\section{Delimitation of the Project}

Postcolonial theory is a vast field displaying an array of knowledge and discourses which are brought forth by theorists who resist the process of colonization and attempt to break the stereotypical notions that have been associated with them from a colonialist perspective. Hence, this study is delimited to the theory of neo-colonialism. Moreover, having described Manto's larger works in the Literature Review section, this study only focuses on Manto's Letters to Uncle Sam, since these letters explicitly reflect a satire on the Capitalist power and its diverse effects countries in the global south.

\section{Literature Review}

The process of colonization and its nature of deceitfulness, violence, fraudulence, and hatred have been a chaotic time in the history of the world, especially in the context of the Indian subcontinent. It not only exploited the natural resources of the colonized lands, as believed, but also disrupted the whole indigenous cultures that were marked by massive heritage, norms, values, and most importantly language. As a result, a revolutionary movement emerged that is widely known today as Anjuman Tarraqi Pasand Mussanafin-e-Hind, or the Progressive Writers' Movement, which aimed at providing a platform for the writers of the Indian subcontinent to work for the betterment of the society against colonialism and imperialism by writing about the issues of equality, violence, poverty hypocrisy etc.

During the First World War (1914-1918), Kiran (2012) argues that the awakening of labor class and the poor nations evoked a sense of freedom amongst people. It was at this stage that writers such as Prem Chand and Josh Malih Abadi paved the way for the revolutionary movement known as "The Progressive Writers" Movement. They not only wrote about the oppressors, but the oppressed too. They explored the outrageous attitudes of the colonizers; the suppressed desires of the societies, highlighted their ignorance, narrow-mindedness and violations of basic human rights. In addition to this, World War Two (1939-1945) took place to make the world 
witness a drastic chaos killing people in Berlin, bombarding Spain and India tyrannized by colonizers. Consequently, in order to secure literature, a movement was held by Gorky, Thomas Mann and other writers who arranged an International Conference where a great number of writers participated from all regions across the globe, in which the Indian writers had already contributed to its development. The first manifesto was held in London, and its agenda, as explained by Sadiq (1983), was that the new body of literature should pay its concern towards the basic problems of our existence today such as violence, power, poverty, social backwardness etc.

Before this movement, Akhter (1971) argues, the Urdu literature had a different lens of viewing the world which was primarily characterized by imaginative fantasies, far from the reality. It was, therefore, the "Progressive Movement" that brought literature to deal with concrete facts. Akhter (1971) adds, “...Never before was Urdu literature proved a vehicle for some movement nor was creativity considered a tool to profess some manifesto..." (p. 221)

The aim of the Progressive Movement was to address domestic issues such as poverty, exploitation and violence, which all came as a result of capitalism and imperialism and their negative effects were felt everywhere. In 1936, the first meeting of the All-India Progressive Movement was held in Lucknow, where Ahmed Ali defined the movement as a shift from escapism towards the acceptance of the social reality by criticizing the uselessness of old conventions, and to guide the mankind towards a new and better way of life. Later, the second meeting of Progressive Movement was held in Culcutta in 1939 which included revolutionary writers such as Sajjad Zaheer, Krishan Chand, Rajinder Singh Bedi, Saadat Hassan Manto, Ismat Chughtai and Faiz Ahmed Faiz etc. These writers sought to expose the tyranny of imperialism, labor oppression and the issues of women. They raised voice against the inequality, injustices, the narrow-mindedness and dictatorship.

Dasgupta (2009) defines the themes of The Progressive Movement as marked by the exploration of nostalgia and despair, the victimization of women, the diurnal trauma in railway platforms and the struggle in the refugee colonies, which have been mirrored in the novels, poems, short stories and letters of these writers.

Das (1996), however, satirized the dumbness of the condition which the progressive writers were involved in exposing since the language was itself brutalized. Nevertheless, no matter how much language is brutalized, it still served the purpose of exposing traumatic experiences of colonization and partition movement. As Kaul (2014) argues that the partition time not only narrates the incidents of our past, but also defines the collective future.

These issues are exceedingly significant when it comes to the work of Saadat Hasan Manto, who was completely against imperialism and neo-colonialism, because he had already seen the later outcomes which neo-colonialism was going to have on the lives of people.

Since colonization took place in 1857, after the declaration of Pakistan as an Independent state in 1947, history offered a large context for the Progressive Writers to produce fiction. The emotionally charged people and their fights for freedom against the tyranny of colonialism provided the authors with a great reservoir of literary material. Ultimately, in order to grapple the enormity of the miserable condition, writers sought to deploy the images of rape, violence, poverty etc, thus presenting life as a completely precarious phenomenon which is only subject to destruction.

Tiwari (2014) defines the madness that is mirrored in Manto's literary pieces. The movement of partition was mainly characterized by an atmospheric madness, and eventually, turning the victims into mad people losing their mental stability under the heavy influence of the traumatic experience. Riyaz on the other hand defines the characters of Manto's literary pieces as similar to Manto himself. Manto seems to identify himself with his characters so much so that his letters known as Letters to Uncle Sam are addressed by his name.

This clearly illustrates the view that Manto himself has been under the traumatic experience and his powerful and poignant writing style expose the hypocritical condition of that time. Issar (1996), on the other hand, defines Manto's work as characterized by a "liminal" zone. He argues that Manto's stories are produced in a liminal space where borders are erased, and consciousness intermingles between sanity and madness, health and sickness, moral values and hypocrisy to be clearly demarcated. As mentioned earlier, the Progressive Writers' Movement aimed to mirror the objective reality that was haunted by the traumatic experience. In this regard, Champfleury (1857) argues that the objective reality aims at producing a realistic representation of the working and poor class with no exaggeration of adding romantic elements of dramatization.

Daruwalla (1996) has skillfully described the crafts of Manto. He argues that the works of Manto are characterized by an instinct to unravel the evil nature and the foolishness of the masses who act as ignorant people. Therefore, Manto bombards the obscenity and sudden violence by explicitly stating the taboos prevailing 
in the society. Most of his works reflect a sense of nationalism and a force for uplifting the society.

In another work by Aggarwal \& Verma (2015), the writers argue that the stories of Manto such as "The Wild Cactus" "The Insult" and "My Name is Radha" are characterized by heavy force of voicing the mutes. Manto criticizes the societal norms by making the dejected people as characters of his stories.

A larger number of studies have been carried out on Manto's short stories from different angles including Feminist studies, Psychoanalysis, pre-partition and Post-partition period, etc. However, when it comes to the letters by Saadat Hassan Manto which are titled as Letters to Uncle Sam (1951) that have been translated in 2002, a single work has been produced by his grandniece Ayesha Jalal (n. d.) who critically analyzes Manto's letters during the time America was about to sign a military assistance agreement. Hence, she goes on to elaborate the satirical nature of Manto in criticizing the American agenda of achieving the American dream of idealizing the world into a global harmony under the traits of globalization. Since no work has been produced in Pakistan or abroad on Manto's letters from a postcolonial perspective, the present study, being postcolonial in nature, aims to analyze Manto's Letters to Uncle Sam from a neo-colonial perspective and explore the ways "The American Dream" has been satirically criticized by Manto through mocking the western agenda.

\section{Theoretical Framework for the Study}

The present study has its grounding in neo-colonialism. It seeks to interpret Manto's letters in relation to Nkrumah's (1965) theory of neo-colonialism. The reason why this theorist has been chosen is because his theory was produced at the time during which the colonized states such as Pakistan were in the process of gaining stability after it got independence from the colonizers. Thus, this theory clearly explicates the economic and political situation of that time, and hence, observes the means through which a new body of colonial agenda in the form of neo-colonialism was being produced.

It was the Great War in 1914-1918 that brought into view the significant quality of the rise of imperialism when a struggle between "the great powers" for a hegemonic control over the colonized countries and their natural and economic resources was underway. As Lenin (1920) puts in his preface of Imperialism that capitalism has definitely grown up to a colonial oppression through the control of finance and economy of the majority of people by a number of advanced countries and "booty is shared between two or three powerful armed to the teeth (America, Great Britain, Japan), who are drawing the whole world into their war over the division of their booty" (Lenin, 1920, p. 10).

For this purpose, a redefinition of imperialism had to take place, which not only aimed at describing the relationship between foreign policies, but also a redefinition of the capitalist nature of reproduction. Lenin (1920) points out that if it were to give the most possible definition, Imperialism would be defined as "the monopoly stage of Capitalism". He adds that it:

"would include what is most important, for, on the one hand, finance capital is the bank capital [i.e., the money capital] of a few big monopolist banks, merged with the capital of the monopolist associations of industrialists; and, on the other hand, the division of the world is the transition from a colonial policy which has extended without hindrance to territories unseized by any capitalist power, to a colonial policy of monopolist possession of the territory of the world, which has been completely divided up." (Lenin, 1920, p. 10).

Therefore, the process of decolonization and the end of direct control over the colonized nations did not absolutely mean that there was a complete erasure of the western hegemony upon the colonized nations. Instead, the indirect control still continues to exist today through imperialism and neo-colonialism which are heavily manifested in colonial discourses.

An indirect control over the colonized nations by means of economic and political growth is what has been defined as neo-colonialism. Some theorists attribute the development of neo-colonialism in the work of Jean-Paul Sartre in 1956, who was a leading anti-colonial social activist. Others mark its development in the work of Leninism, where it was described as a new form of domination. However, the term "neo-colonialism" received international acclaim when Nkrumah (1965), the leading exponent of pan-Africanism, published his book Neo-Colonialism: The Last Stage of Imperialism (1965). The reason for the development of neo-colonialism was based on the fact that there was no way for the super power such as the United States to exert a direct control after the post-war era, and the inability to return to the pre-war condition where there was a deep gulf between the few rich colonies and the many poor. Neo-colonialism therefore represents the best and the most dangerous form of colonialism in the world of today. In fact, Nkrumah (1965) argues that neo-colonialism was a more insidious process and extremely hard to resist than the direct exertion of classic 
colonialism.

Once a colonial territory has transformed into a dependent state, it cannot be reversed to its previous condition. Thus, according to Nkrumah (1965), neo-colonialism has developed where a state which might apparently seem as an independent sovereign subject, has in reality, its political policies and economic systems directed from outside. This can be accomplished in many forms such as the imperial power may garrison the neo-colonial state and control its government. Where neo-colonialism exists, the exercise of power is usually drilled by the state that formerly colonized the lands. However, this is not always the case. For instance, the Indian subcontinent has been ruled by the British Empire, but the neo-colonial control over it has been exercised by the State is by America.

Nkrumah (1965) argues that the end of the nineteenth century regarded the colonies as a source of wealth which could only help in mitigating and reducing class conflicts in the Capital States. However, the Capitalist States failed in their theory objects because the pre-war Capitalist States were so much internally organized that the bulk of wealth possession went down into the pockets of the Capitalist class and not to the workers. Moreover, it is argued that the new elite which is formed out of a colonial independence, is brought to power and trained by the colonialist powers, was unrepresentative of their people and were thus compradors for the former colonial rulers.

Nkrumah (1965) argues that even non-aligned countries fall prey to neo-colonial agendas. In this policy, a non-aligned country receives foreign investment from a capitalist state. The matter is not of what the investor is going to receive, but instead is a question of power which results in a maximum degradation of the non-aligned State. A state that is in the grip of neo-colonialism falls prey to its master and not to its own destiny. Nkrumah (1965) defines neo-colonialism at its best "power without responsibility and for those who suffer from it, it means exploitation without redress". (Nkrumah, 1965, p. 5)

Defining neo-colonialism as an insidious process is therefore clearly justifiable. In order to make it attractive to those upon whom it is practiced, Nkrumah (1965) argues that it must be shown as capable of raising their living standards, instead of actually making one. However, the economic objective of neo-colonialism is not to raise the standard of living, but to keep those standards depressed in the interest of the developed countries, and in order to do so, a list of innumerable "aid programs" are initiated.

To elaborate Nkrumah's theory, Ashcroft, Griffiths \& Tiffin (2007) argue that neo-colonialism is based on the principle that the larger united territories may be divided into small States that cannot operate individually and have no means of development, and hence, have to rely on the imperial power for their political and economic growth, under the pressure of globalization. The effect of neo-colonialism has led to the development of globalization, which is defined as the process by which the local communities and individual lives are affected by the economic and superpowers that operate worldwide. Therefore, the rapid growth of globalization reflects a change in the world-wide social relations where local communities and individuals are affected by the economic realities that bypass the boundaries of the State. Globalization has been defined from two perspectives: on the one hand, it is viewed as a positive feature of changing the world through forms of technologies, industries and rapid economic growth that will benefit the local communities and individuals leading them to prosperity, peace and freedom as Albrow (1994) defines globalization as a term for "for values which treat global issues as a matter of personal and collective responsibility" (Albrow, 1994, p. 4). On the other hand, it is viewed as a negative discursive power created by the dominant first world countries to have control over the third world countries by erasing the distinction of individual societies under a homogeneous global culture, and therefore, the local economies are incorporated under a system of global capital through which power is generated and operated. Ferguson (1993) argues that globalization has "ideological overtones of historical inevitability" and "its attendant myths function as a gospel of the global market" (p. 87).

\section{Methodology of the Study}

The present study is embedded in the theory of Post colonialism. It, therefore, adopts a qualitative approach and seeks to conduct a textual analysis of Saadat Hassan Manto's Letters to Uncle Sam from the perspective of Neo-colonialism. It attempts to address the issues of globalization within a Pakistani context and critically analyzes Manto's satirical words in the light of neo-colonialism.

\section{Analysis and Discussion}

Saadat Hassan Manto (1912-1955) is regarded as one of the pioneers of Urdu Literature. The pivotal themes of his literary works are an effect of the destabilization of the world that he witnessed during the colonial and post-colonial era. Therefore, he is considered as an immediate postcolonial Urdu writer because he had 
experienced the traumatic incidents and violence at first hand. The magnificent writings titled Letters to Uncle Sam are one of the exceedingly significant literary texts of Manto which have unfortunately been neglected by most of the theorists. His letters provide the reader with a critical insight into the drastic effects of neocolonialism and the negative effects of globalization. Being a postcolonial writer, Manto aims at satirizing the Western dominant power that is the United States in his seminal work Letters to Uncle Sam.

By the time Pakistan was newly established as an independent state, the United State was rising to its utmost power. Therefore, being a superpower, America began to aid Pakistan through military possessions. Consequently, Pakistan, being a subordinate to the United States because of its position at the receiving end, had to ultimately agree upon the terms and conditions with America. Manto, understanding the ways in which the military aid was colonizing his country, detested that. His satirical remarks in the letters stood as a proof of his repudiation for the hidden agendas of the hegemonic power was establishing over Pakistan. In his first letter, he addresses Uncle Sam and states that "my country is not your country which I regret" (First Letter to Uncle Sam, 1951, p. 1). In this two pronged satirical remark, Manto verbally attacks both his country and the US. In an ironical tone, Manto gives out a message to the US that he can see how his country has been taken over by the US in its entirety that it would have been better had it been a part of the US. On the other hand, in the same statement, Manto questions the bureaucratic powers of Pakistan by becoming their mouthpiece. He uses the words of the bureaucracy and highlights the way they have accepted to be governed by the US. Thus, with US becoming a Global Power, this has consequently given rise to neo-colonialism. Therefore, where apparently a state seems independent in its economic and political system, it is indirectly being controlled by the super power.

Manto sees the ways in which America creates discourses to manipulate the masses. Manto's fourth letter attempts to make the readers see through imperialism. He indicates the agendas behind America's aid. He draws a clear picture of America's own interest in sending out aid. As mentioned in Manto's "Fourth Letter to Uncle Sam":

"Regardless of India and the fuss it is making, you must sign a military pact with Pakistan because you are seriously concerned about the stability of the world's largest Islamic state since our mullah is the best antidote to Russian communism. Once military aid starts flowing, the first people you should arm are these mullahs. They would also need American-made rosaries and prayer-mats, not to forget small stones that they used to soak up the after-drops following a call of nature. Cut-throat razors and scissors should be top of the list, as well as American hair-colour lotions. That should keep these fellows happy and in business..." (Fourth Letter to Uncle Sam, 1954, p. 1)

Manto (1951) keeps up with his ability to be brutally honest and clearly debunking in unveiling the motives behind America's aid, which Nkrumah (1965) has identified as a means of neo-colonialism. He sarcastically highlights that America's interest does not lie in the stability of the world; rather it lies in upholding in what it believes is right. Manto (1951) debunks the hidden reality of the American Dream when he writes a sarcastic account indicating America's exceptionalism. By stating that America wants the stability of the world's largest Islamic state because it can be used against the beliefs that America does not support, Manto (1951) reveals the motives behind American aid through which it is exercising control over Islamic states merely to fight against communism. Another noticeable thing is that, Manto (1951) has not only resisted the political ideologies of the capitalist super power but has, in fact, directly satirized the western ridiculous notions of globalization that are a complete misfit in the context of the Indian subcontinent. Helen Tiffin (1995) gives the term "counter discursive strategies" (Helen Tiffin, 1995, p. 96), and claims that the greatest strength of postcolonial writers is not the modification of Western ideologies, thus producing colonial discourses as a result, but is instead marked by an ability to counter these discourses by resisting the stereotypical assumptions about the colonized. Manto (1951) not only highlights the background agenda but also shows a discursive resistance towards political ideologies of the hegemonic power.

The "First Letter to Uncle Sam" is exceedingly significant as a postcolonial writing. Manto (1951) aims at criticizing the Western hegemony being practiced on the colonized nations. He resists the Western dominance in the first paragraph of his letter, as mentioned below, and aims to satirize the newly established Super Power which is indirectly controlling and manipulating the then newly established Pakistan, so much so that the country never becomes independent of any form of imperial design. Consequently, being a postcolonial social critic, Manto (1951) uses the metaphor of a "bird" as a symbol of freedom and independence, and points his finger towards America to claim that while Pakistan has been under colonialist suppression before it has been established as an independent country, it is still mentally and physically subjugated by the Super power, just as a bird that has lost its feathers to fly: 
"You should know why my country, sliced away from India, came into being and gained independence, which is why I am taking the liberty of writing to you. Like my country, I too have become independent and in exactly the same way. Uncle, I will not labour the point since an all-knowing seer like you can well imagine the freedom of a bird whose wings have been clipped can enjoy."(First Letter to Uncle Sam, 1951, p. 1)

Manto's ironical tone manages to make its way even in these lines. He shows the lack of freedom that his country has by comparing it to the lack of freedom of expression Manto faced. He ironically states that he is independent whereas actually he is not. In a colonized state, independence is always lost. The same is true for neocolonialism. As defined by Nkrumah (1965), neo-colonialism is one of the most insidious processes through which an apparently independent state is actually still holding a subaltern status. Being a revolutionary writer, Manto satirizes the effects of neo-colonialism that have sprung upon the world. As he says in his first letter:

"My country is poor. It has no art paper, nor proper printing presses. I am living evidence of this poverty. You will not believe it, uncle, but despite being the author of twenty-two books, I do not have my own house to live in. And you will be astonished to know that I have no means of getting myself from one place to the other. I neither have a Packard nor a Dodge; I do not even have a used car." (First Letter to Uncle Sam, 1951, p. 1)

As Nkrumah (1965) argues that the result of neo-colonialism is, therefore, not an increase in the development of the developing lands, but is a maximum exploitation resulting in an absolute degradation in terms of economic wealth and political policies. It, thus, continues to increase rather than decrease the gap between the rich lot and the poor nations. Consequently, Manto (1951) criticizes the negative effects of neo-colonialism that it has engendered upon Pakistan. The continuous repetition of elements like poverty, shame and violence in statements such as "I am poor because my country is poor" (First Letter to Uncle Sam, 1951, p. 1) are actually being highlighted as effects of neo-colonialism.

Chaudhry (2012) defines poverty as the lack of material, social and emotional resources for a standard living. Thus, poverty is a condition of social exclusion where a large number of marginalized individuals are constrained from taking an active part in the social, cultural and other spheres of life due to their lack of income and support by the elite state. According to Nkrumah (1965), the elite stratum of a once colonized country is brought to power and dominance, and is trained by the colonialists; therefore, it consequently serves the means of the colonialists rather than the state and proves to be unrepresentative of its nation. This claim clearly justifies Fanon's idea of Black skin white Masks in a neo-colonial perspective, since the later adheres to the notions stated by Fanon (1961), who says that the greatest effect of colonialism is the transfer that it brings into lives of the colonized, thus attempting to westernize the non-westernized. Manto (1951) goes on to highlight this point in his first essay and aims to resist the ignorance of his country which is agreeing upon the terms and conditions assigned by the US, hence although it is brown by nature, it is mentally subjugated and still controlled by the white people, as he says:

"My country is poor, but why is it ignorant? I am sure, uncle, you know why because you and your brother John Bull together are a subject I do not want to touch because it will not be exactly music to your ears. Since I write to you as a respectful youngster, I should remain that way from start to finish." (First Letter to Uncle Sam, 1951, p. 2)

It is argued that writers, who experience poverty, are characterized by a peculiar harshness in their tone and boldness in their writings. The first issue of Naya Adab (New Literature, April, 1939) as a major publication of Progressive writers' Movement sought to expose the oppression of the society, critically evaluate them, reflect upon them, and provide them with an alternative means of leading a better way of life. Being a revolutionary writer of Naya Adab, the harshness and distress that is prevalent in Manto's writing originates from the social deprivation which his country has been through, such as its unbefitting financial position:

"If I need to go somewhere, I rent a bike. If a piece of mine appears in a newspaper and I earn twenty to twenty-five rupees at the rate of seven rupees a column, I hire a tonga and go buy locally distilled whiskey. Had this whiskey been distilled in your country, you would have destroyed that distillery with an atom bomb because it is the sort of stuff guaranteed to send its user to kingdom come within one year." (First Letter to Uncle Sam, 1951, p. 1)

These lines hold great significance when viewed from the perspective of the impact of globalization. Postcolonial theorists view globalization as the emergence of power relations as a western legacy of imperialism, and the means through which the local communities are engaged in the force of globalization reflect the ways colonized nations appropriate and engage in the force of imperial designs. Therefore, as Fanon (1961) argues in 
his essay "The Wretched of the Earth" that decolonization does not simply end with the evaporation of colonial means from the colonized societies, but is instead a continuous process that has emerged in the form of neo-colonialism and globalization, adding that:

"We should flatly refuse the situation to which the Western powers wish to condemn us. Colonialism and imperialism have not paid their score when they withdraw their flags and their police forces from our territories" (Fanon, 1961, p. 101), and instead centuries will be required to humanize the world that has been brought down to the level of animals by an imperial design.

As explained earlier, globalization is taken in two layers of meanings. On the one hand, it is presented as a positive phenomenon which harmonizes all cultures together, making it a "melting pot". The melting pot theory was claimed to be in place in the United States to present a platform where all the nations of the world, being heterogeneous, could come to terms with each other to become homogenized in one pot. However, as mirrored in Manto's letters, he explicitly rejects this idea and attempts to show the follies and fraudulence of his nation for blindly supporting the imperialist agendas under the mask of globalization. For this reason, Ferguson (1993) accuses globalization as a political ideology in which the local economies are not only disrupted, but the global culture and global economy are also erupted and continue to perpetuate a capital power, which ultimately produces an unequal power distribution. Manto (1951) critically satirizes the impact globalization in his fourth letter. Globalization did not only benefit the capitalist power in rising its economy but has also "transferred" the ideologies of the mankind making them highly westernized so much so that Manto argues that even the mullahs (Muslim clerics) had to bend down towards the American ideology, as he writes:

"If this gang of mullahs is armed in the American style, the Soviet Union that hawks communism and socialism in our country will have to shut shop. I can visualize the mullahs, their hair trimmed with American scissors and their pajamas stitched by American machines in strict conformity with the Sharia. The stones they use for their after-drops of you-know-what will be American, untouched by human hand, and their prayer-mats would be American, too. Everyone will then become your camp follower, owing allegiance to you and no one else..." (Fourth Letter to Uncle Sam, 1954, p. 1)

The reason why globalization has risen up was, according to Ferguson (1993), an imperial design through which the capitalist power can exercise its hegemonic ideologies upon the world, thus erupting the whole indigenous cultures by bringing up a "global market" so that all the subordinate states may look down upon themselves and would instead follow the American Dream of establishing a prosperous and peaceful life to every human being, as Manto writes in his Third Letter:

"I like the American way of life. I also like the design of your casual-wear shirt. It is both a good design and a good billboard. You can print the latest propaganda item on it every day and move from Shezan to Coffee House to Chinese Lunch Home so that everyone can read it. I also want a Packard so that when I go riding in it on the Mall, wearing that shirt with a pipe gifted by you resting between my teeth, all the progressive and nonprogressive writers of Lahore should come to realize that they have been wasting their time so far." (Third Letter to Uncle Sam, 1954, p. 1)

This has resulted in instilling a fear in the Muslim nations which was rapidly turning towards the adoption of a colonial mentality. David \& Okazaki (2006) define a "colonial mentality" as a cultural and ethnic inferiority of the beliefs of colonized lands by valuing the beliefs and attitudes of the dominant western hegemony. Colonial mentality is viewed as a form of racial oppression, where the colonized nations internalize the ideological belief that they are less human than others, and therefore, due to this inferiority, they are subject to follow the imperial design. Entering such frame of mind is mainly due to the negative stereotyping that manifests itself in various forms, including xenophobia and islamophobia, the two phenomena which witnessed new heights in the post 9/11 global north. (Awan, 2010; 2013)

Finding itself in such a vulnerable state of mind, the Muslim community would lose its distinctive essence, the "binary of the Self and the Other", or the "politics of difference" (Masood. xix). As Manto (1951) states in his "Eight Letter to Uncle Sam":

"No-whatever happens, I'm yours. That one time you gave me three hundred rupees bought my loyalty for life" (Eight Letter to Uncle Sam, 1954, p. 133).

However, being a postcolonial writer, Manto (1951) not only satirizes the capitalist dominance that runs its hegemonic power through economic exploitation, but he also resists these imperial designs and forges his local culture, as Patke defines it, as a "call to indigenization" (Patke, 2006, p. 8) as a counter discursive strategy to answer or write back to the colonizers. Manto (1951) writes in his Eighth Letter: 
"There's this hair-oil made from cherry plums and jasmine that we love because it's marketed as a Muslim product. We might be dumb but we are very loyal people! God! Please keep us just as we are!" (Eight Letter to Uncle Sam, 1954, p. 135)

The mention of local products as a means of economic development is exceedingly significant, because Manto aims at resisting globalization. As Robertson (2007) coins the term "Glocalization" (as cited in Osterhammel \& Peterson, 2005, p. 7) to imply that globalization has "an impact on local communities and requires special "absorption" that is "often interpreted as "hybridity", which means that the result of the new cultural elements are creatively adapted to mesh with the existing ones," (Osterhammel \& Peterson, 2005, p. 7). Thus, with the mention of local hair-oils, Manto attempts to "glocalize" the capitalist economic nature within indigenous products, making them more preferable especially for Pakistan.

Although satirical in nature, Manto (1951) attempts to rejuvenate a national sense of Muslim identity in his Eighth Letter by continuously inviting Uncle Sam (The United States) towards Islamization, as he says: "That's why my advice is to adopt Islam as your national religion so that you won't feel like you have to take advantage of your victory over Japan to produce a race of ill-begotten children" (Eighth Letter to Uncle Sam, 1954, p. 135). In this vein, Mansoor (2012) argues that the loss of self under the imperialist agenda has to be reversed, and Iqbal (2010) proposes a panacea in the form of Islam, as not only a set of dogma, but a mechanism for resistance against the preoccupying western assumptions. To sum it up, Masood (2010) argues:

"The native is not just demanding inclusion within the colonial system; he is, rather, offering his own philosophical and political ideology as a solution to the problems of the colonial masters. This alternative against the dominance of the West is presented in the shape of a universal Islamic system. It is this system of politics and culture that forms the basis of his idea of a Muslim Nation." (120)

\section{Conclusion}

This research, therefore, sought to answer the basic two research questions which have been postulated at the start of the project. It can be viewed from the aforementioned discussion that colonialism does not end with the colonizers leaving the lands of the colonized states, but instead, it leaves behind them a creed of Sahibs, who are an assimilated array of the colonizers who can, at best, maintain the western hegemonic ideologies within their lands. Therefore, the process of colonialism then adopts a new means of an imperialist agenda which can be described at its best as neo-colonialism. The process of generating a new means of imperialist agenda through neo-colonialism is extremely dangerous, because it makes a nation mentally subjugated by imposing the western ideologies upon them through means of globalization, thus building a global market which directs the whole economic, political and belief systems of the other states.

However, with every forced control, there comes a form of cultural and political resistance by an attempt to create a political and national independence. Resistance is not only articulated by means of wars against the colonizers to erase them from the lands, but is also constantly introduced, defined and redefined in the course of history through (counter)narratives. Therefore, a postcolonial theory was then needed as a distinct discipline to generate narratives in order to counter the colonial discourse, and the only way, in the context of the Indian subcontinent was to produce this platform through the Progressive Writers Movement that fought against the tyranny of colonial suppression, and resisted the western political ideologies such as rising nations through building a so-called global system or harmonizing all cultures under one "melting pot". Manto, therefore, resists the political dogmas of the Super Power, by directly satirizing its ideologies and notions which it has brought to a country where it became a complete misfit. As a result, in order to resist and counter these ideologies, the (in)famously liberal Manto satirizes the United States, by continuously inviting Uncle Sam towards Islam. In doing so, Manto not only resists the Western imperialist agenda, but also attempts to define the very heterogeneity in the form of customs and the local heritage of his nation, thus implanting a space within the narratives of history to define his state's individuality.

\section{References}

Aggarwal, A., \& Verma, P. (2015). Voicing the Mutes. An International Refereed e-Journal of Literary Explorations, 3(4).

Akhter, S. (1971). Urdu Adabki Mukhtasir Tareekh. (Short History of Urdu Literature) Lahore: Sang-e Mil Publications. Print.

Albrow, M. (1994a). Globalization: Myths and Realities. Inaugural Lecture, London: Roehampton Institute.

Albrow, M. (1994b). Local / global relations in a London borough. London: Dept. of Sociology and Social Policy, Roehampton Institute of Higher Education. 
Ashcroft, B., Griffiths, G., \& Tiffin, H. (Eds.). (1995). The post-colonial studies: A reader's guide. London: Routledge.

Awan, S. M. (2010). Global Terror and the Rise of Xenophobia/Islamophobia: An Analysis of American Cultural Productions Since September 11. Islamic Studies, 49(4), 521-537.

Awan, S. M. (2013). Unwilled Choices: The Exilic Perspectives on Home and Location in the Works of Zulfikar Ghose and Mohsin Hamid. Pakistaniaat, 5(2). Retrieved from http://pakistaniaat.org/index.php/pak/article/view/225/232

Bagchi, J., \& Dasgupta, S. (2009). The trauma and the triumph: Gender and partition in eastern India. Kolkata: Street.

Champfleury, J. (1857). Le Realisme (p. 2). Paris: Michel Lévy.

Daruwalla, K. N. (1996). The Craft of Manto, Warts and All. Annual of Urdu Studies, 11. Center for South Asia, University of Wisconsin-Madison. Retrieved from http://digital.library.wisc.edu/1793/11931

Das, V. (1994). Mirrors of violence: Communities, riots and survivors in South Asia. Delhi: Oxford University Press.

Das, V. (1996). Language and body: transactions in the constructions of pain. Daedalus, 125, 67-91.

David, E. J., \& Okazaki, S. (2006). Colonial Mentality Scale for Filipino Americans. Psyc TESTS Dataset.

Fanon, F. (1952). Black Skin: White Masks. Translated by Charles Lam Markmann. London: MacGibbon and Kee (1968).

Fanon, F. (1961). The Wretched of the Earth. Translated by Constance Farrington. New York: Grove. Cited in Ashcroft et al. 1995.

Ferguson, M. (1993). The Myth about Globalization. European Journal of Communication, (7), 69-93.

Issar, D. (1996). Manto: The Image of the Soul in the Mirror of Eros. Tr. M. Asaduddin and Alok Bhalla Conference; Life and works of Saadat Hasan Manto. Ed. AlokBhalla. Simla: Indian Institute of Advanced study.

Judd, D. R., \& Swanstrom, T. (1998). City politics: Private power and public policy. New York.

Lenin, V. I. (1968). Imperialism, the highest stage of capitalism: A popular outline. Moscow: Progress Publishers.

Longman, K. S. (2014). Eighteenth-Century British Literature and Postcolonial Studies. Modern Philology, 111(4). Chicago: The University of Chicago Press.

Mansoor, A. (2012). The Notes of a New Harp: Tracing the Evolution of Pakistani poetry in English. Pakistaniaat: A Journal of Pakistan Studies, 4(1), 14-38.

Nkrumah, K. (1965). Neo-colonialism. The last stage of imperialism. London.

Osterhammel, J., and Neils, P. P. (2005). Globalization: Circumnavigating a Term. Globalization: A Short History. Princeton, USA: Princeton University Press.

Patke, R. S. (2006). Postcolonial Poetry in English. NY: OUP.

Raja, M. A. (2010). Constructing Pakistan: Foundational Texts and the Rise of Muslim National Identity. 1857-1947.

Riyaz, T. (1996). Saadat Hasan Manto: Ideology and Social Philosophy. Tr. Riaz Punjabi. Conference: Life and works of Saadat Hasan Manto. Ed. Alok Bhalla. Shimla: Indian Institute of Advanced Study.

Sadiq, M. (1983). Twentieth Century Urdu Literature. Karachi: Royal Book Company.

Sartre, J. P. (2006). Colonialism and Neocolonialism. London: Routledge.

Suvir Kaul. (2014). The Partitions of Memory: The Afterlife of the divisions of India. New Delhi: Permanent Black, 2003.

Tiffin, H. (1995). Post-Colonial Literatures and Counter-Discourse. In B. Ashcroft, G. Griffiths, \& H. Tiffin (Eds.), The Post-Colonial Studies Reader (pp. 95-98). London: Routledge.

Tiwari, S. (2014). Memories of Partition: Revisiting Saadat Hasan Manto. Economic and Political Weekly, 25.

Ullah, I., \& Arif, M. (2013). Writing Back to the Empire: Righting Creole Identity in Wide Sargasso Sea. 
Language in India, 13(6), 256-266.

Wolfe, P. (1997). History and Imperialism: A Century of Theory, from Marx to Postcolonialism. The American Historical Review, 102(2), 388-420. https://doi.org/10.2307/2170830

\section{Copyrights}

Copyright for this article is retained by the author(s), with first publication rights granted to the journal.

This is an open-access article distributed under the terms and conditions of the Creative Commons Attribution license (http://creativecommons.org/licenses/by/4.0/). 